\title{
Proteases in pathogenic and nonpathogenic haemoflagellates, Cryptobia spp. (Sarcomastigophora: Kinetoplastida), of fishes
}

\author{
X. Zuo, P. T. K. Woo* \\ Department of Zoology, University of Guelph, Guelph, Ontario, Canada N1G 2W1
}

\begin{abstract}
Proteases were detected in Cryptobia salmositica (pathogenic and nonpathogenic vaccine strains), $C$. bullocki, and $C$. catostomi using azocasein and hide powder azure as substrates. Maximum activity occurred in acidic $\mathrm{pH}$ and the pathogenic strain of $C$. salmositica had the highest activity. Cysteine protease was found in pathogenic and nonpathogenic Cryptobia spp., but metallo-protease was only present in the pathogenic strain of $C$. salmositica. Five enzymatic bands were detected in the pathogenic C. salmositica using haemoglobin-SDS-PAGE: four of these were cysteine proteases $(49,60$, 66 and $97 \mathrm{kDa})$ and the other was a metallo-protease $(200 \mathrm{kDa})$. The pathogenic C. salmositica lost the metallo-protease after 10 mo of in vitro culture. We suggest that the metallo-protease of the pathogenic C. salmositica is related to pathogenicity of the parasite.
\end{abstract}

KEY WORDS: Cryptobia salmositica $\cdot$ C. bullocki $\cdot$ C. catostomi $\cdot$ Cysteine protease $\cdot$ Metallo-protease

\section{INTRODUCTION}

Cryptobia spp. have been described from the gills, body surface, digestive tract, and blood of freshwater and marine fishes. Although a few species are pathogenic to fish, many are not known to cause disease (Woo 1987, 1991, 1994).

Cryptobia salmositica is a pathogenic haemoflagellate of salmonids on the Pacific coast of North America (Woo 1987, 1994). Infected fish develop anaemia, anorexia, exophthalmia, abdominal distension with ascites, general edema, and splenomegaly (Woo 1979, Li \& Woo 1991). Serial in vitro culture of C. salmositica in minimum essential medium resulted in a strain that produced no clinical disease but protected adult (Woo \& Li 1990, Li \& Woo 1995) and juvenile (Sitja-Bobadilla $\&$ Woo 1994) rainbow trout from disease. Cryptobia bullocki is a pathogenic haemoflagellate in estuarine and marine flat fishes along the Atlantic coast of North America. The clinical signs of the disease include lethargy, anaemia, abdominal distension with ascites, and splenomegaly (Burreson 1982a, b). Cryptobia cato-

·Addressee for correspondence. E-mail: pwoo@uoguelph.ca stomi is a nonpathogenic haemoflagellate of white suckers in Ontario, Canada. Though high parasitaemias occur in naturally and experimentally infected fish, there are no clinical signs associated with the infection (Bower \& Woo 1977a, b, Thomas \& Woo 1992).

Proteases which hydrolyse peptide bonds are found in all organisms and are separated into 4 major classes [serine, cysteine (thiol), metallo, and aspartyl (carboxy) protease] based on the important chemical groups in their active sites. Parasite proteases are presumed to facilitate invasion of host tissues, allow parasites to digest host proteins, help parasites evade the host immune response, and prevent blood coagulation (McKerrow 1989). Nothing is known about the proteolytic enzymes of Cryptobia. The aims of the present study are to characterize and quantify the major protease(s) of pathogenic and nonpathogenic Cryptobia species.

\section{MATERIALS AND METHODS}

Cryptobia salmositica and C. bullocki were cultured as described earlier (Woo \& Thomas 1991) and C. catostomi was cultured in TDL-15 medium supplemented 
with $2 \%$ white sucker serum (Li \& Woo 1996). The blood form of C. salmositica (pathogenic strain) was isolated from an infected rainbow trout and subsequently cultured for no more than 2 mo, at which time the parasite is still pathogenic to trout (Woo \& Thomas 1991). This was to obtain a large number of parasites free of host cells. C. salmositica (vaccine strain) and C. bullocki had been in continuous in vitro culture for about 7 and $8 \mathrm{yr}$, respectively. The C. catostomi was from the blood of a naturally infected white sucker and maintained in the laboratory by blood inoculation into laboratory raised suckers.

Sample preparation. All procedures, unless otherwise stated, were carried out at $4^{\circ} \mathrm{C}$. Parasites harvested from the late log phase were washed 3 times with $0.25 \mathrm{M}$ sucrose by centrifugation at $7000 \times \mathrm{g}$ for $10 \mathrm{~min}$. A washed pellet containing about $5 \times 10^{7}$ cells was suspended in $1 \mathrm{ml}$ of $0.1 \mathrm{M}$ phosphate buffer ( $\mathrm{pH} 6.5$ ) containing $0.2 \%$ Triton $\mathrm{X}-100(\mathrm{v} / \mathrm{v})$, and sonicated for $5 \mathrm{~min}$, and followed by 3 freeze and thaw cycles. After centrifugation at $7000 \times g$ for $20 \mathrm{~min}$, the supernatant was pooled and used immediately or stored at $-100^{\circ} \mathrm{C}$. Storage at $-100^{\circ} \mathrm{C}$ did not decrease proteolytic activities.

Protein concentration of the samples was determined using the method of Bradford (1976).

Protease assays. Proteolytic activities were assayed using azocasein (AZC) (North \& Walker 1984) and hide powder azure (HPA) (North \& Whyte 1984) as substrates with slight modifications. Briefly, $100 \mu$ l of the cell lysate (containing $100 \mu \mathrm{g}$ protein) was incubated with $0.5 \mathrm{ml}$ of either AZC (Sigma, $10 \mathrm{mg} \mathrm{ml}^{-1}$ ) or $0.5 \mathrm{ml}$ HPA (Sigma, $10 \mathrm{mg} \mathrm{ml}^{-1}$ ) and $0.5 \mathrm{ml}$ buffer at $37^{\circ} \mathrm{C}$. The incubation time was $2 \mathrm{~h}$ with $\mathrm{AZC}$ or $4 \mathrm{~h}$ with $\mathrm{HPA}_{;} 0.2 \mathrm{ml}$ of $50 \%$ trichloroacetic acid (TCA) was then added to terminate the reaction and the tube left to stand at $4^{\circ} \mathrm{C}$ for $30 \mathrm{~min}$. The insoluble material was removed by centrifugation and the dye released was determined spectrophotometrically at $520 \mathrm{~nm}$ for the AZCase and $595 \mathrm{~nm}$ for the HPAase against the blank (the same incubation solution but with no cell lysate). The activity is given in unit $(1 \mu \mathrm{g}$ substrate protein hydrolysed per hour per mg protein of the lysate). An increase of 1 absorbency unit was caused by the hydrolysis of $0.71 \mathrm{mg} \mathrm{AZC}$ and $3.4 \mathrm{mg}$ HPA under the reaction conditions (North \& Walker 1984, North \& Whyte 1984). The buffers used to determine $\mathrm{pH}$ effects on protease activity were $0.1 \mathrm{M}$ phosphate buffer ( $\mathrm{pH} 3.0$ to 7.0 ) and $0.1 \mathrm{M}$ Tris- $\mathrm{HCl}$ buffer ( $\mathrm{pH} 7.5$ to 9.0).

Inhibition of proteases. The method used was that described by North et al. (1983). All the inhibitors used in this study were purchased from Sigma Chemical Company, Mississauga, Canada. Briefly, cell lysate was preincubated with inhibitors for $30 \mathrm{~min}$ at $25^{\circ} \mathrm{C}$ before adding the substrate. The concentrations of in- hibitors used for the preincubation were 10 to $20 \mu \mathrm{M}$ E-64 (L-trans-epoxysuccinyl-leucylamidi-4-guanidinobutane) or 1 to $2 \mathrm{mM}$ of PMSF (phenylmethylsulphonyl fluoride), or phenanthroline, or IAA (iodoacetamide), or TLCK (N-a-p-tosyl-L-lysine chloromethyl ketone); 100 to $200 \mu \mathrm{g} \mathrm{ml}^{-1}$ of pepstatin, or leupeptin, or chymostatin, or antipain. Stock solutions of inhibitors in methanol (phenanthroline, chymostatin, pepstatin, or PMSF) or in water (all other inhibitors) were prepared at 20 times the required concentration. Appropriate control was preincubated with either water or methanol (but with no inhibitor).

Activation of proteases. Protease hydrolysis was also assayed in the presence of each of the following cysteine protease activators (Sigma): $1.0 \mathrm{mM}$ DTT (dithiothreitol), or $5.0 \mathrm{mM}$ EDTA (ethylene diamine tetraacetic acid), or $1.0 \mu \mathrm{g} \mathrm{ml}^{-1}$ cysteine (Garber \& Lemchuk-Favel 1989). The activators were preincubated with the lysate as was done with the inhibitors.

Substrate SDS-PAGE. Polyacrylamide gel electrophoresis using SDS (sodium dodecyl sulfate)-discontinuous buffer system (SDS-PAGE) was performed as described by Hames (1981). The substrate-SDS-PAGE was performed as above except that the haemoglobin $(0.2 \% \mathrm{w} / \mathrm{v})$ was incorporated into the $7.5 \%$ running gel. The haemoglobin, a blood protein substrate, was extracted and prepared from the blood of an uninfected rainbow trout according to the method of Knox et al. (1993). A $20 \mu$ volume of cell lysate (containing $20 \mu \mathrm{g}$ protein) was mixed with $10 \mu \mathrm{l}$ of SDS-sample buffer $(0.5 \mathrm{M}$ Tris- $\mathrm{HCl}$, pH 6.8, $10 \%$ SDS, $20 \%$ glycerol and $0.02 \%$ bromophenol blue) without a reducing agent and without boiling. The sample was then applied to the gel and electrophoresed using a BioRad Mini-protean system (BioRad Ltd, Canada) with a constant current of $12 \mathrm{~mA}$ per gel at $4^{\circ} \mathrm{C}$. After electrophoresis the gels were immersed in $1 \mathrm{l}$ of $2.5 \%(\mathrm{v} / \mathrm{v})$ Triton X-100 for $1 \mathrm{~h}$ to remove the SDS and were washed once with incubation buffer $(0.1 \mathrm{M}$ phosphate buffer, pH 5.0 or 7.0). The protease bands were developed by immersing the gels in the incubation buffer for $12 \mathrm{~h}$ at $37^{\circ} \mathrm{C}$.

To determine the effects of inhibitors on the development of the protease bands, some strips of the gels were incubated in the buffer containing either E-64 $(20 \mu \mathrm{M})$ or phenanthroline (1 mM). Zones of proteolysis were clear bands against a blue background after Coomassie Blue staining. Molecular weight of individual protease was determined from their mobility relative to those of protein standards.

Statistical analysis. Student's $t$-test (Wardlaw 1985) was used to determine significant difference in protease activities between different Cryptobia spp. and between either inhibition or activation of proteases and controls. Results were considered significant if $\mathrm{p}<0.05$. 


\section{RESULTS}

\section{Effects of $\mathrm{pH}$ on proteolytic activity}

Proteolytic activities were detected in cell lysates of all Cryptobia spp. using either AZC or HPA as the substrate (Fig. 1). In all cases, proteolytic activities were significantly higher at acidic $\mathrm{pH}$ than at either neutral or alkaline $\mathrm{pH}$. All activities were maximal between $\mathrm{pH} 3.5$ and 4.5, and the optimal pH differed with both substrate and species/strain of Cryptobia (Fig. 1).

The optimal protease activity varied between species and strains of Cryptobia (Fig. 1). At optimal pH, the C. salmositica (blood form) had much higher activity than the other species or strain $(p<0.05)$; it was nearly 2 -fold higher than that in the vaccine strain.

\section{Classification of major classes of proteases by using standard inhibitors}

Proteolytic activities in Cryptobia spp. were not inhibited by the serine protease inhibitor, $\mathrm{PMSF}_{\text {, nor }}$ by the aspartyl protease inhibitor, pepstatin (Table 1). However, proteolytic activities of all Cryptobia spp. were significantly inhibited by E-64 (Table 1), indicating that cysteine protease was present in all Cryptobia spp. E-64 is a powerful inhibitor and at only $20 \mu \mathrm{M}$ it completely inhibited the proteolytic activities of the vaccine strain of $C$. salmositica and C. catostomi. Phenanthroline, an inhibitor of metallo-protease, significantly reduced the proteolytic activities of the blood form of $C$. salmositica but not those of the vaccine

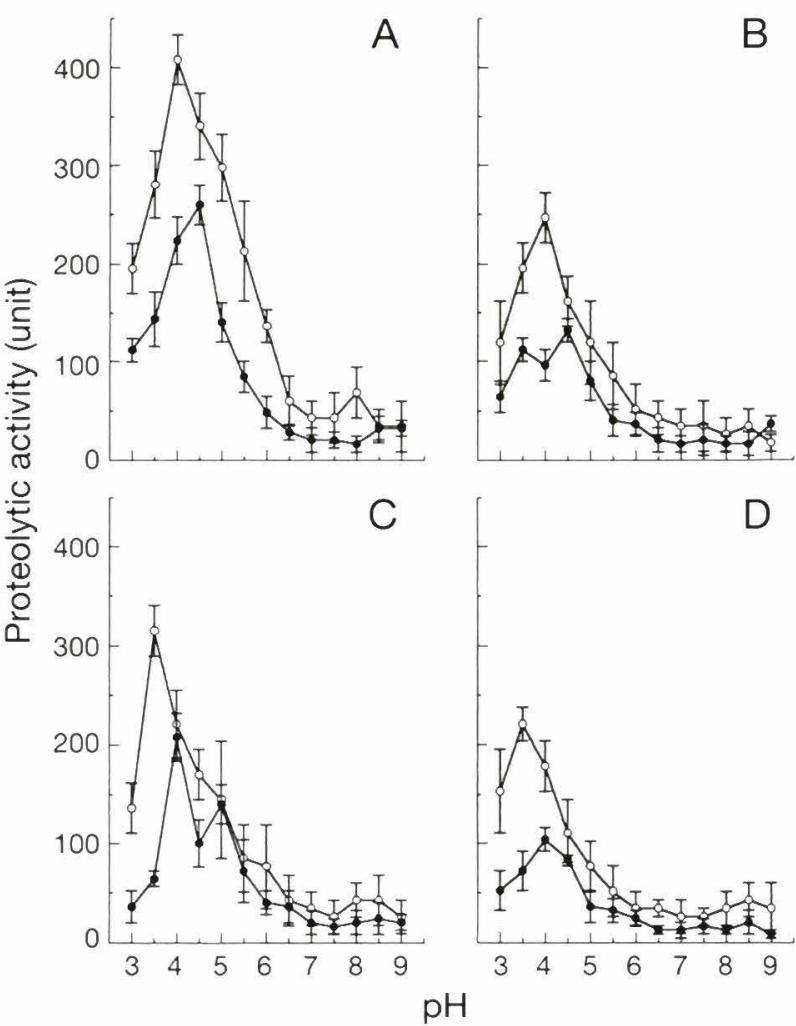

Fig. 1. Effects of pH on proteolytic activities of Cryptobia spp. (A) C. salmositica (blood form); (B) C. salmositica (vaccine strain); (C) C. bullocki; (D) C. catostomi. The buffers used were $0.1 \mathrm{M}$ phosphate buffer ( $\mathrm{pH} 3.0$ to 7.0 ) and $0.1 \mathrm{M}$ Tris$\mathrm{HCl}$ buffer ( $\mathrm{pH} 7.5$ to 9.0 ). Each point is mean \pm standard deviation from 3 independent determinations. Proteolytic activity is given in units ( $\mu$ g substrate hydrolysed per hour per mg protein of enzyme). (•) using AZC as substrate; (0) using HPA as substrate

Table 1. Effects of protease inhibitors on proteolytic activity of Cryptobia spp. Activity remaining (with the inhibitor) was given as a percentage $(\%)$ of the control (without the inhibitor); mean \pm standard deviation from 3 independent determinations. PMSF: phenylmethylsulphonyl fluoride; E-64: L-trans-epoxysuccinyl-leucylamidi-4-guanidino-butane

\begin{tabular}{|c|c|c|c|c|c|c|c|c|}
\hline \multirow[t]{2}{*}{$\begin{array}{l}\text { Inhibitors } \\
\text { (protease clas }\end{array}$} & \multicolumn{2}{|c|}{$\begin{array}{l}\text { C. salmositica } \\
\text { (blood form) }\end{array}$} & \multicolumn{2}{|c|}{$\begin{array}{l}\text { C. salmositica } \\
\text { (vaccine) }\end{array}$} & \multicolumn{2}{|c|}{ C. bullocki } & \multicolumn{2}{|c|}{ C. catostomi } \\
\hline & $\begin{array}{l}\text { AZCase } \\
\text { (pH 4.5) }\end{array}$ & $\begin{array}{l}\text { HPAase } \\
(\mathrm{pH} \mathrm{4.0)}\end{array}$ & $\begin{array}{l}\text { AZCase } \\
(\mathrm{pH} \mathrm{4.5)}\end{array}$ & $\begin{array}{l}\text { HPAase } \\
(\mathrm{pH} \mathrm{4.0)}\end{array}$ & $\begin{array}{l}\text { AZCase } \\
(\mathrm{pH} \mathrm{4.0)}\end{array}$ & $\begin{array}{l}\text { HPAase } \\
(\mathrm{pH} 3.5)\end{array}$ & $\begin{array}{l}\text { AZCase } \\
\text { (pH 4.0) }\end{array}$ & $\begin{array}{l}\text { HPAase } \\
(\mathrm{pH} 3.5)\end{array}$ \\
\hline \multicolumn{9}{|c|}{ PMSF: (serine-) } \\
\hline $1 \mathrm{mM}$ & $99.5 \pm 12.0$ & $98.6 \pm 7.5$ & $97.9 \pm 14.1$ & $94.0 \pm 12.5$ & $107.2 \pm 18.5$ & $97.1 \pm 12.8$ & $113.9 \pm 20.9$ & $94.0 \pm 6.9$ \\
\hline $2 \mathrm{mM}$ & $101.9 \pm 7.5$ & $102.3 \pm 14.0$ & $88.5 \pm 11.5$ & $95.5 \pm 18.2$ & $98.9 \pm 6.0$ & $98.3 \pm 16.1$ & $105.6 \pm 23.6$ & $104.2 \pm 18.9$ \\
\hline \multicolumn{9}{|c|}{ Pepstatin: (aspartyl-) } \\
\hline $100 \mu \mathrm{g} \mathrm{ml}^{-1}$ & $102.1 \pm 8.0$ & $95.5 \pm 8.2$ & $95.7 \pm 12.4$ & $101.2 \pm 10.9$ & $113.8 \pm 19.7$ & $98.1 \pm 7.4$ & $115.3 \pm 14.7$ & $103.0 \pm 6.9$ \\
\hline $200 \mu \mathrm{g} \mathrm{ml}^{-1}$ & $102.0 \pm 9.4$ & $111.6 \pm 7.0$ & $84.6 \pm 7.7$ & $90.9 \pm 18.2$ & $102.3 \pm 10.6$ & $103.5 \pm 12.6$ & $116.7 \pm 10.1$ & $109.7 \pm 9.5$ \\
\hline \multicolumn{9}{|c|}{ Phenanthroline: (metallo-) } \\
\hline $1 \mathrm{mM}$ & $73.3 \pm 5.0^{\circ}$ & $70.9 \pm 7.5^{\circ}$ & $91.4 \pm 6.7$ & $82.1 \pm 12.9$ & $84.4 \pm 11.2$ & $79.0 \pm 7.2$ & $89.7 \pm 10.5$ & $84.7 \pm 6.4$ \\
\hline $2 \mathrm{mM}$ & $61.0 \pm 7.1^{\circ}$ & $66.0 \pm 8.5^{\circ}$ & $86.7 \pm 6.6$ & $88.0 \pm 10.0$ & $82.2 \pm 11.1$ & $84.0 \pm 16.0$ & $90.5 \pm 9.5$ & $90.0 \pm 10.0$ \\
\hline \multicolumn{9}{|c|}{ E-64: (cysteine-) } \\
\hline $10 \mu \mathrm{M}$ & $30.4 \pm 5.4^{\bullet}$ & $27.7 \pm 8.5^{\circ}$ & $10.0 \pm 6.6^{\circ}$ & $16.0 \pm 8.0^{\circ}$ & $20.0 \pm 6.7^{\circ}$ & $25.0 \pm 6.3^{\bullet}$ & $14.3 \pm 4.8^{\circ}$ & $10.0^{\circ} \pm 5.0^{\circ}$ \\
\hline $20 \mu \mathrm{M}$ & $23.2 \pm 7.1^{\bullet}$ & $21.3 \pm 6.4^{\bullet}$ & $0^{\bullet}$ & $0^{\bullet}$ & $8.9 \pm 2.2^{\circ}$ & $9.4 \pm 3.1^{\bullet}$ & $0^{\circ}$ & $0^{\bullet}$ \\
\hline
\end{tabular}


Table 2. Effects of cysteine protease inhibitors on proteolytic activity of Cryptobia spp. Activity remaining (with the inhibitor) was given as a percentage of the control (without the inhibitor); mean \pm standard deviation from 3 independent determinations. TLCK: N-a-p-tosyl-L-lysine chloromethyl ketone; IAA: iodoacetamide

\begin{tabular}{|c|c|c|c|c|c|c|c|c|}
\hline \multirow[t]{2}{*}{ Inhibitors } & \multicolumn{2}{|c|}{$\begin{array}{l}\text { C. salmositica } \\
\text { (blood form) }\end{array}$} & \multicolumn{2}{|c|}{$\begin{array}{l}\text { C. salmositica } \\
\text { (vaccine) }\end{array}$} & \multicolumn{2}{|c|}{ C. bullocki } & \multicolumn{2}{|c|}{ C. catostomi } \\
\hline & $\begin{array}{l}\text { AZCase } \\
(\mathrm{pH} 4.5)\end{array}$ & $\begin{array}{l}\text { HPAase } \\
\text { (pH 4.0) }\end{array}$ & $\begin{array}{l}\text { AZCase } \\
(\mathrm{pH} 4.5)\end{array}$ & $\begin{array}{l}\text { HPAase } \\
\text { (pH 4.0) }\end{array}$ & $\begin{array}{l}\text { AZCase } \\
(\mathrm{pH} \mathrm{4.0)}\end{array}$ & $\begin{array}{l}\text { HPAase } \\
\text { (pH 3.5) }\end{array}$ & $\begin{array}{l}\text { AZCase } \\
(\mathrm{pH} \mathrm{4.0)}\end{array}$ & $\begin{array}{l}\text { HPAase } \\
\text { (pH 3.5) }\end{array}$ \\
\hline \multicolumn{9}{|l|}{ TLCK: } \\
\hline $1 \mathrm{mM}$ & $17.5 \pm 4.2$ & $35.6 \pm 7.0^{\circ}$ & $10.4 \pm 4.7$ & $13.1 \pm 7.4$ & $33.4 \pm 4.5^{\circ}$ & $30.4 \pm 7.4$ & $9.7 \pm 6.4$ & $18.2 \pm 4.6$ \\
\hline $2 \mathrm{mM}$ & $18.9 \pm 7.5^{\circ}$ & $27.9^{\prime} 9.3^{\circ}$ & 0 & 0 & $15.9 \pm 6.8^{\circ}$ & $17.2 \pm 6.9^{\circ}$ & 0 & 0 \\
\hline \multicolumn{9}{|l|}{ Leupeptin: } \\
\hline $100 \mu \mathrm{g} \mathrm{ml}^{-1}$ & $32.8 \pm 5.8^{\circ}$ & $40.9 \pm 10.0^{\circ}$ & $25.8 \pm 6.5$ & $48.8 \pm 12.5$ & $30.4 \pm 4.6^{\circ}$ & $40.0 \pm 8.6$ & $14.9 \pm 5.3$ & $27.8 \pm 8.7$ \\
\hline $200 \mu \mathrm{g} \mathrm{ml}^{-1}$ & $30.4 \pm 7.1^{\circ}$ & $31.9 \pm 8.5^{\circ}$ & 0 & 0 & $15.6 \pm 4.4^{\circ}$ & $18.8 \pm 6.3^{\circ}$ & 0 & 0 \\
\hline \multicolumn{8}{|l|}{ Chymostatin: } & $242+69$ \\
\hline $200 \mu \mathrm{g} \mathrm{ml}^{-1}$ & $\begin{array}{l}3 f .3 \pm 0.4 \\
28.3 \pm 5.7 .\end{array}$ & $34.9 \pm 9.3^{\circ}$ & $\begin{array}{c}25.0 \pm 0.3 \\
0\end{array}$ & $\begin{array}{c}25.0 \pm 10 . t \\
0\end{array}$ & $\begin{array}{r}32.0 \pm f .8 \\
9.1 \pm 3.2\end{array}$ & $\begin{array}{l}40.1 \pm 10.3 \\
17.2 \pm 4.5^{\circ}\end{array}$ & $\begin{array}{c}10 . + \pm 11.1 \\
0\end{array}$ & $\begin{array}{c}24.2 \pm 0.9 \\
0\end{array}$ \\
\hline \multicolumn{9}{|l|}{ Antipain: } \\
\hline $100 \mu \mathrm{g} \mathrm{ml}^{-1}$ & $18.9 \pm 5.9^{\circ}$ & $28.4 \pm 6.4$ & $8.6 \pm 4.9$ & $22.6 \pm 9.0$ & $55.6 \pm 8.9^{\circ}$ & $60.9 \pm 9.2^{\circ}$ & $5.7 \pm 5.2$ & $19.4 \pm 6.4$ \\
\hline $200 \mu \mathrm{g} \mathrm{ml}^{-1}$ & $17.9 \pm 5.4^{\circ}$ & $21.3 \pm 6.3^{\circ}$ & 0 & 0 & $15.6 \pm 2.2^{\circ}$ & $15.6 \pm 3.1^{\circ}$ & 0 & 0 \\
\hline \multicolumn{9}{|l|}{ IAA: } \\
\hline $1 \mathrm{mM}$ & $50.0^{\circ} \pm 10.0^{\circ}$ & $41.7 \pm 12.5^{\circ}$ & $43.0 \pm 11.3$ & $38.1 \pm 12.5^{\circ}$ & $41.1 \pm 8.6$ & $49.5 \pm 13.5^{\circ}$ & $21.8 \pm 8.7$ & $13.9 \pm 4.8$ \\
\hline $2 \mathrm{mM}$ & $32.1 \pm 7.1^{\circ}$ & $34.0 \pm 8.5^{\circ}$ & 0 & 0 & $17.8 \pm 6.7^{\circ}$ & $24.0 \pm 4.0^{\circ}$ & 0 & 0 \\
\hline
\end{tabular}

strain of C. salmositica, C. bullocki and C. catostomi (Table 1), showing that metallo-protease is only present in the pathogenic strain of C. salmositica.

\section{Effects of cysteine protease inhibitors on proteolytic activities}

Proteolytic activities in all Cryptobia spp. were significantly inhibited by the following cysteine protease inhibitors: TLCK, leupeptin, chymostatin, antipain and IAA (Table 2), thus confirming that cysteine protease was present in all Cryptobia spp. tested. Proteases of the blood form of C. salmositica and C. bullocki were significantly less sensitive to these cysteine protease in- hibitors than that of $C$. catostomi (Table 2). However, there were no significant differences $(p>0.05)$ between proteases of the nonpathogenic C. catostomi and of the vaccine strain of $C$. salmositica in their sensitivity to most inhibitors. Proteolytic activities in the vaccine strain of C. salmositica and C. catostomi were completely blocked by cysteine protease inhibitors at $2 \mathrm{mM}$ or $200 \mu \mathrm{g} \mathrm{ml}^{-1}$, indicating that only cysteine protease was present in nonpathogenic Cryptobia.

\section{Activations of the cysteine protease}

Three cysteine protease activators (DTT, EDTA and cysteine) were used on protease assays at their optimal

Table 3. Effects of cysteine protease activators on proteolytic activity of Cryptobia spp. Activity remaining (with the activator) was given as a percentage (\%) of the control (without the activator); mean \pm standard deviation from 3 independent determinations. DTT: dithiothreitol; EDTA: ethylene diamine tetraacetic acid

\begin{tabular}{|c|c|c|c|c|c|c|c|c|}
\hline \multirow[t]{2}{*}{ Activators } & \multicolumn{2}{|c|}{$\begin{array}{l}\text { C. salmositica } \\
\text { (blood form) }\end{array}$} & \multicolumn{2}{|c|}{$\begin{array}{l}\text { C. salmositica } \\
\text { (vaccine) }\end{array}$} & \multicolumn{2}{|c|}{ C. bullocki } & \multicolumn{2}{|c|}{ C. catostomi } \\
\hline & $\begin{array}{l}\text { AZCase } \\
(\mathrm{pH} \mathrm{4.5)}\end{array}$ & $\begin{array}{l}\text { HPAase } \\
\text { (pH 4.0) }\end{array}$ & $\begin{array}{l}\text { AZCase } \\
(\mathrm{pH} \mathrm{4.5)}\end{array}$ & $\begin{array}{l}\text { HPAase } \\
\text { (pH 4.0) }\end{array}$ & $\begin{array}{l}\text { AZCase } \\
(\mathrm{pH} \mathrm{4.0)}\end{array}$ & $\begin{array}{l}\text { HPAase } \\
(\mathrm{pH} 3.5)\end{array}$ & $\begin{array}{l}\text { AZCase } \\
(\mathrm{pH} \mathrm{4.0)}\end{array}$ & $\begin{array}{l}\text { HPAase } \\
(\mathrm{pH} 3.5)\end{array}$ \\
\hline $\begin{array}{l}\text { DTT } \\
(1.0 \mathrm{mM})\end{array}$ & $239.3 \pm 12.9^{\bullet}$ & $279.8 \pm 18.0^{\circ}$ & $268.8 \pm 24.7^{\circ}$ & $301.2 \pm 38.5^{\bullet}$ & $268.9 \pm 19.0^{\circ}$ & $299.0 \pm 11.5^{\circ}$ & $279.3 \pm 31.0^{\circ}$ & $344.4 \pm 31.6^{\circ}$ \\
\hline $\begin{array}{l}\text { Cysteine } \\
\left(1.0 \mu \mathrm{g} \mathrm{ml}^{-1}\right.\end{array}$ & ${ }_{1)}^{295.5} \pm 13.5^{\circ}$ & $248.6 \pm 28.3^{\circ}$ & $277.4 \pm 40.4^{\circ}$ & $298.8 \pm 23.8^{\bullet}$ & $420.7 \pm 13.4^{\circ}$ & $424.7 \pm 43.4^{\circ}$ & $220.7 \pm 17.3^{\circ}$ & $195.8 \pm 12.5^{\circ}$ \\
\hline $\begin{array}{l}\text { EDTA } \\
(5.0 \mathrm{mM})\end{array}$ & $99.4 \pm 8.4$ & $108.3 \pm 11.6$ & $138.7 \pm 11.1^{\circ}$ & $127.4 \pm 6.3^{\circ}$ & $123.3 \pm 8.0^{\circ}$ & $125.3 \pm 7.2^{\bullet}$ & $123.0 \pm 8.0^{\circ}$ & $127.8 \pm 8.7^{\circ}$ \\
\hline
\end{tabular}


pH (Table 3). DTT and cysteine significantly increased protease activity. However, EDTA only activated proteases from the vaccine strain of Cryptobia salmositica, C. bullocki and C. catostomi $(\mathrm{p}<0.05)$ but not the protease from the blood form of $C$. salmositica ( $p>0.05$ ). EDTA is both an activator of cysteine protease and an inhibitor of metallo-protease; the blood form of $C$. salmositica had both cysteine and metallo-proteases (Table 1); hence there was no net increase in the activity of proteases by using EDTA.

\section{Detection of pathogenic Cryptobia salmositica proteases using haemoglobin-SDS-PAGE}

The banding pattern of the pathogenic Cryptobia salmositica proteases was studied using haemoglobinSDS-PAGE (Fig. 2). There were 5 protease bands (200, 97, 66, 60 and $49 \mathrm{kDa}$ ) after the gel was incubated in the buffer alone ( $\mathrm{pH}$ 5.0). However, 3 protease bands (66, 60 and $49 \mathrm{kDa}$ ) were not detected and the activity (or density) of the $97 \mathrm{kDa}$ protease band was considerably reduced after the gel was incubated with E-64 (at $10 \mu \mathrm{M}$ in the incubation buffer) (Fig. 2); this identified the 4 bands as cysteine proteases. The band with the highest molecular mass (200 kDa) was not affected by E-64 but it was not detected after the gel was incubated with phenanthroline (at $1 \mathrm{mM}$ in the incubation buffer) (Fig. 2); this identified it as a metallo-protease.

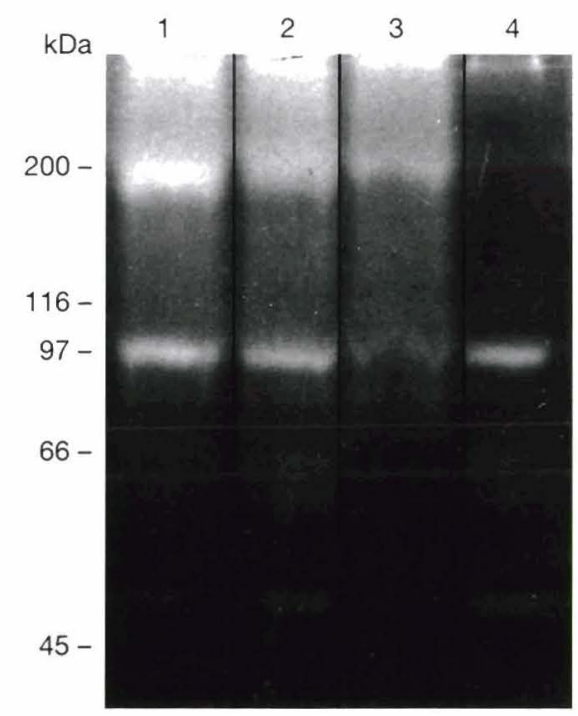

Fig. 2. Proteases of pathogenic Cryptobia salmositica detected using haemoglobin-SDS-PAGE. The protease bands were developed in $0.1 \mathrm{M}$ phosphate buffer at $\mathrm{pH}$ 5.0. Lanes 1 and 2: the gel was incubated in buffer alone; Lane 3: the gel was incubated with E-64 (10 $\mu \mathrm{M}$ in the buffer); lane 4: the gel was incubated with phenanthroline (1 $\mathrm{mM}$ in the buffer).

Standard molecular mass markers $(\mathrm{kDa})$ as indicated

\section{Effects of prolonged in vitro culture on protease activity}

Proteolytic activities (with either AZC or HPA as the substrate) of Cryptobia salmositica (blood form) at 6 mo were significantly lower $(\mathrm{p}<0.05)$ than those at 2 mo of culture, and the activities at 10 mo were still significantly. lower $(\mathrm{p}<0.05)$ than those at 6 mo of culture (Fig. 3). This indicates that proteolytic activities of the pathogenic $C$. salmositica decreased significantly during 10 mo of continuous culture. However, there were no significant changes in proteolytic activities of the other Cryptobia spp. (Fig. 3).

Cysteine protease of the pathogenic Cryptobia salmositica remained with prolonged in vitro culture, since leupeptin significantly inhibited the protease activity $(p<0.05)$ throughout the 14 mo of culture (Table 4). However, the metallo-protease in the parasite was lost after 10 mo of culture. Phenanthroline only significantly reduced the protease activity at 2 and 6 mo of the culture $(\mathrm{p}<0.05)$, but did not significantly reduce it at 10 and 14 mo of culture $(p>0.05)$ (Table 4 ).

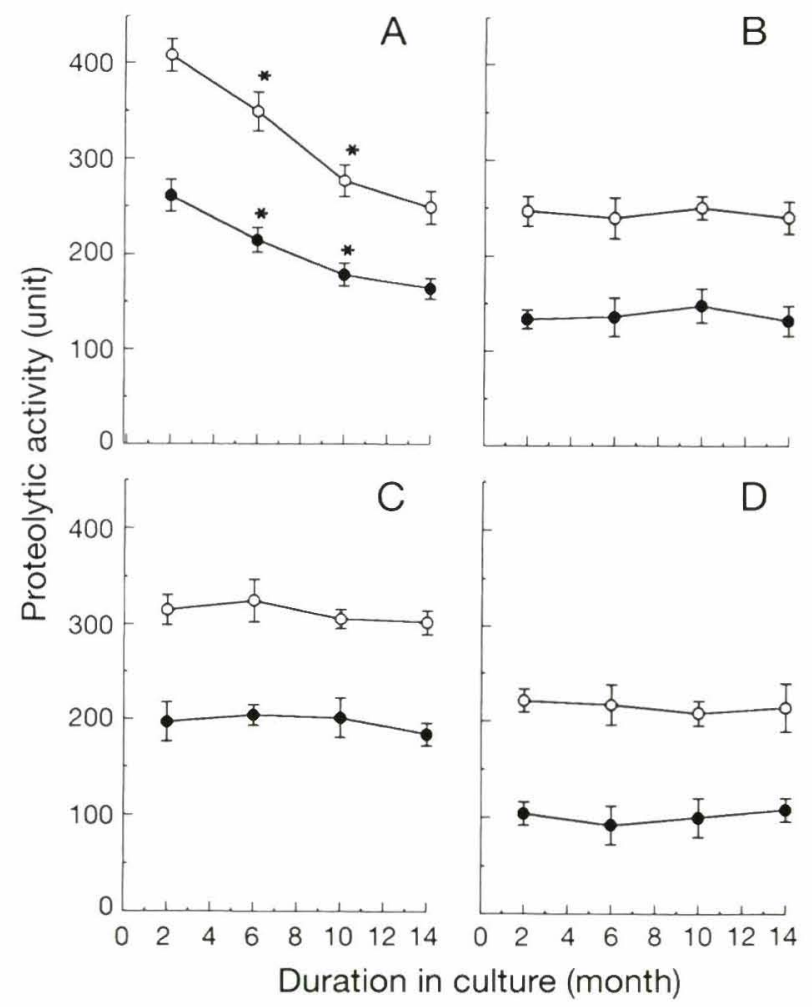

Fig. 3. Proteolytic activities of Cryptobia spp. during prolonged in vitro culture. (A) C. salmositica (blood form); (B) C. salmositica (vaccine strain); (C) C. bullocki; (D) C catostomi. Each point is mean \pm standard deviation from 3 independent determinations. Proteolytic activity is given in units ( $\mu \mathrm{g}$ substrate hydrolysed per hour per mg protein of enzyme). (•) Using AZC as substrate; (0) using HPA as substrate. 'Significantly lower $(p<0.05)$ compared with the previous point 
Table 4. Effects of protease inhibitors on proteolytic activities of pathogenic Cryptobia salmositica during prolonged in vitro cultivation. Activity remaining after incubation with the inhibitor (either $100 \mu \mathrm{g} \mathrm{ml}^{-1}$ leupeptin or $1 \mathrm{mM}$ phenanthrolin) is given as a percentage (\%) of the control (without the inhibitor); mean \pm standard deviation from 3 independent determinations

\begin{tabular}{|c|c|c|c|c|}
\hline \multirow{2}{*}{$\begin{array}{l}\text { Duration in } \\
\text { culture (mo) }\end{array}$} & \multicolumn{2}{|c|}{ AZCase } & \multicolumn{2}{|c|}{ HPAase } \\
\hline & Leupeptin & Phenanthroline & Leupeptin & Phenanthroline \\
\hline 2 & $36.2 \pm 6.4^{\circ}$ & $72.4 \pm 6.2^{\circ}$ & $49.2 \pm 7.3^{\circ}$ & $69.7 \pm 7.0^{\circ}$ \\
\hline 6 & $27.1 \pm 7.8^{\circ}$ & $69.9 \pm 4.3^{\circ}$ & $44.7 \pm 5.5^{\circ}$ & $71.9 \pm 6.6^{\circ}$ \\
\hline 10 & $27.5 \pm 7.6^{\circ}$ & $84.2 \pm 8.8$ & $42.2^{2} \pm 8.4^{\circ}$ & $84.4 \pm 8.4$ \\
\hline 14 & $21.1 \pm 4.6^{\circ}$ & $89.8 \pm 5.4$ & $35.8 \pm 5.6^{\circ}$ & $85.2 \pm 7.4$ \\
\hline \multicolumn{5}{|c|}{$\begin{array}{l}\text { - Activity was significantly lower }(\mathrm{p}<0.05) \text { than the control (without the } \\
\text { inhibitor) }\end{array}$} \\
\hline
\end{tabular}

The protease banding pattern of the pathogenic Cryptobia salmositica during prolonged in vitro culture was studied using haemoglobin-SDS-PAGE. The activity of the metallo-protease was considerably enhanced and that of the cysteine proteases was reduced after the gel was incubated at pH 7.0 (Fig. 4) compared with those bands developed at pH 5.0 (Fig. 2); this indicates that the metallo- and cysteine proteases had a different optimal $\mathrm{pH}$. At $0,2,6$ mo of culture the pathogen had 5 protease bands (Fig. 4): 1 band was metallo-protease and 4 bands were cysteine proteases. However, the metallo-protease band (about $200 \mathrm{kDa}$ ) was not detected from sample after 10 mo of culture (Fig. 4); this confirms that the parasite lost the metallo-protease with prolonged in vitro culture (Fig. 3, Table 4). Although the activities (or den-

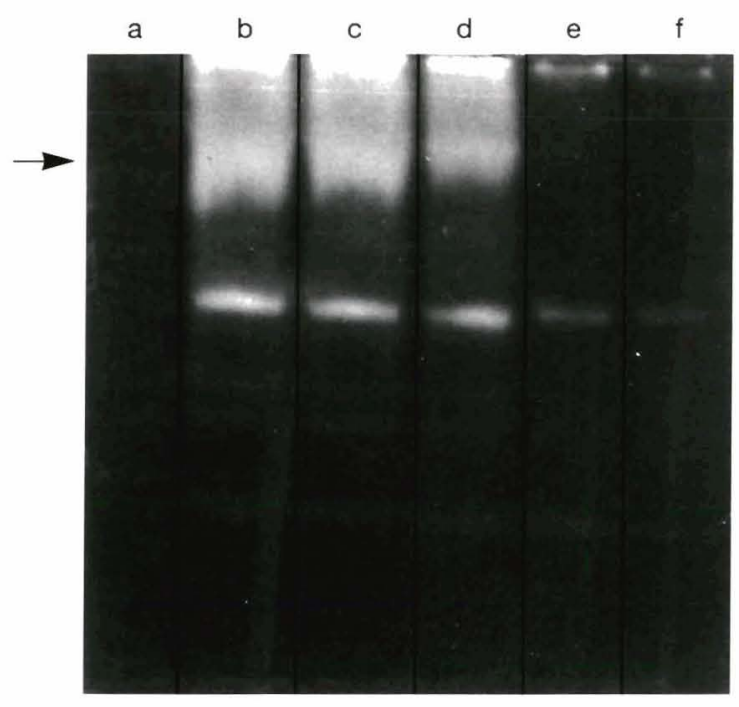

Fig. 4. Proteases of pathogenic Cryptobia salmositica from the different times of in vitro culture detected using haemoglobin-SDS-PAGE. Protease bands were developed at pH 7.0. Lane a: blood cells of an infected rainbow trout; lanes b, c, d, e and $f$ : the parasite at $0,2,6,10$ and 14 mo of culture, respectively. Arrow indicates the metallo-protease band (about $200 \mathrm{kDa}$ ) sity) of 4 cysteine protease bands also decreased, these protease bands were present during 14 mo of culture (Fig. 4). The sample (lane b, Fig. 4 at 0 mo of culture) was contaminated with proteins from host blood cells since the parasite was isolated directly from the blood of an infected rainbow trout. However, no protease band was detected from the blood cells of the rainbow trout (lane a, Fig. 4), indicating that the host blood cells did not affect the detection of $C$. salmositica proteases using the substrate gel electrophoresis.

\section{DISCUSSION}

Substrate-SDS-PAGE has been more widely used than native substrate-PAGE (without SDS) in zymograms of proteases, because in SDS-gels molecular weights of electrophoretically fractionated proteases can be determined (Lacks \& Springhorn 1980, Sarath et al. 1989). The SDS in the gel denatures some proteases but the denatured enzymes appear to recover their activities after the SDS is diffused out of the gel (Lacks \& Springhorn 1980). Using the haemoglobinSDS-PAGE the intracellular proteases of C. salmositica appeared as 5 enzymatic bands (Fig. 2); the same number of protease bands were also detected using native substrate-PAGE (data not shown). We also found that SDS in the gel inhibited or reduced $C$. salmositica protease activities, because when SDS was not diffused out of the gel, 2 minor protease bands ( 60 and $66 \mathrm{kDa}$ ) were not seen and the other 3 protease bands (200, 97 and $49 \mathrm{kDa}$ ) were much weaker (visualized as less clear zone of proteolysis). Hence, we suggest that if SDS is used during electrophoresis, it should be routinely removed by washing the gel in 1 to $2.5 \%$ Triton $\mathrm{X}-100$ for about $1 \mathrm{~h}$ to ensure maximum protease activity when the gel is in incubation buffer. Our study confirms the suggestions of earlier workers (Lacks \& Springhorn 1980, Sarath et al. 1989).

Cysteine (thiol) proteases in parasitic protozoa have been assumed to have metabolic and physiologic roles in these parasites (North 1992). The major protease in Trypanosoma cruzi, a human pathogen in central and south America, is a cysteine protease with chemical properties similar to mammalian cathepsin L (Bontempi et al. 1984, Nazareth et al. 1992, Harth et al. 1993). The purified cysteine protease is able to degrade azocasein and blood protein substrates (e.g. haemoglobin, albumin) at acidic pH (Bontempi et al. 1984). Peptide-fluoromethyl ketone, a specific inhibitor of cysteine protease, arrests intracellular replication of 
the parasite and intercellular transmission. This indicates that the protease functions in intracellular protein degradation and also in remodelling the parasite during transformation between stages (Harth et al. 1993). Peptidyl diazomethane derivatives, a class of irreversible inhibitors for cysteine protease, impair host cell invasion and block the intracellular development of $T$. cruzi; this suggests that the ability to infect and develop intracellularly in mammalian cells is dependent on the activity of its major cysteine protease (Nazareth et al. 1992).

In the present study, cysteine protease was detected in pathogenic and nonpathogenic Cryptobia spp. (Tables 1, 2 \& 3). Nonpathogenic $C$. salmositica and C. catostomi had only cysteine protease and its activity remained unchanged with prolonged in vitro culture (Fig. 3). The total proteolytic activities in the pathogenic strain of $C$. salmositica decreased significantly with prolonged in vitro culture (Fig. 3). However, the cysteine protease at least remained unchanged, whereas the metallo-protease was lost after $10 \mathrm{mo}$ of in vitro culture (Table 4, Fig. 4). The chemical properties (e.g. the sensitivity to inhibitor and activator, optimal $\mathrm{pH}$ ) of the cysteine protease in Cryptobia spp. were similar to those of the cysteine protease in Trypanosoma cruzi (Bontempi et al. 1984). We suggest that cysteine protease in the Cryptobia spp., as in T. cruzi (Bontempi et al. 1984), is important in intracellular protein catabolism (e.g. in digesting exogenous host proteins to obtain free amino acids for protein synthesis); hence the level of the cysteine protease in Cryptobia is quite stable.

Metallo-protease has also been found in parasitic protozoa. The metallo-protease in promastigotes of Leishmania helps the parasite to invade mammalian macrophages by cleaving the host complement factor $\mathrm{C} 3 \mathrm{~b}$ to $\mathrm{C} 3 \mathrm{bi}$; this allows binding of the parasite via C3bi to the macrophage surface (Bouvier et al. 1989, 1990, Etges 1992). A metallo-protease in the trophozoite of Entamoeba histolytica degrades host collagen, suggesting that it plays an important role in the invasion of host tissue (Munoz et al. 1982, 1990). Trypanosoma cruzi also contains metallo-protease which is mainly located in the cell membrane (Greig \& Ashall 1990, Bonaldo et al. 1991). Using gelatin gel electrophoresis, Greig \& Ashall (1990) found multiple proteases in $T$. cruzi epimastigotes: 4 bands are cysteine proteases and 1 band was a metallo-protease. This protease pattern is quite similar to what we found in the pathogenic Cryptobia salmositica using haemoglobin gel electrophoresis (Fig. 2). T. cruzi trypomastigotes penetrate cells and tissues and a surface or secreted protease is involved in penetration of cells (Piras et al. 1985); it was proposed that the metalloprotease might play an important role in host cell invasion (Greig \& Ashall 1990, Bonaldo et al. 1991).
The pathogenic strain of Cryptobia salmositica lost its virulence after $1 \mathrm{yr}$ of serial in vitro cultivation (Woo \& Li 1990); however, its virulence was not reduced on short-term (e.g. 2 mo) culture (Woo \& Thomas 1991). In the present study there was a significant loss of metallo-protease activity after 10 mo of continuous in vitro culture (Figs. $3 \& 4$, Table 4 ). We suggest that the decrease in activity of the metallo-protease is related to the loss of virulence in the pathogenic strain of $C$. salmositica.

Two basic haemolytic components (a lytic component and an immune complex-forming component) in the pathogenic Cryptobia salmositica are responsible for the anaemia in rainbow trout (Thomas \& Woo 1988). The lytic component lyses red blood cells independent of antibody/complement, whereas the immune complex-forming component attaches to red blood cells forming immune complexes with specific antibody and activates complement resulting in haemolysis (Thomas $\&$ Woo 1988). These are also secreted by C. salmositica under in vitro conditions (Woo \& Thomas 1992).

The biochemical nature of the haemolytic components of Cryptobia salmositica is not clear, though it is believed to be proteinaceous in nature (Thomas \& Woo 1989). In the present study metallo-protease was only found in the pathogenic strain of C. salmositica and the activity of metallo-protease significantly decreased with prolonged in vitro culture. In another investigation we (Zuo \& Woo 1997) demonstrated that the purified metallo-protease from the pathogenic C. salmositica causes in vitro lysis of fish red blood cells and that the enzyme is secreted by the parasite into the blood of infected fish. We suggest that the metallo-protease is likely the 'secreted haemolytic component' detected in earlier studies (Thomas \& Woo 1988, 1989, Woo \& Thomas 1992). Although C. bullocki causes anaemia in flatfishes, metallo-protease was not found in our present strain probably because it has been in continuous in vitro culture for more than $8 \mathrm{yr}$ in our laboratory. It is likely that our $C$. bullocki strain has lost its virulence with prolonged in vitro culture as did our C. salmositica strain. C. catostomi was freshly isolated and is not known to cause anaemia in fish (Thomas \& Woo 1992), and no metallo-protease was detected in the nonpathogenic $C$. catostomi and the vaccine strain of C. salmositica (Table 1). Further research into the biochemical nature of the metallo-protease in virulent C. salmositica would provide us with a better understanding of the mechanism of the disease in salmonid cryptobiosis.

Acknowledgements. This study was supported by the grants from the Department of Fisheries and Ocean (Canada) and the Natural Sciences and Engineering Research Council (Canada) to P.T.K.W. 


\section{LITERATURE CITED}

Bonaldo MC, D'Escoffier LN, Salles JM, Goldenberg S (1991) Characterization and expression of proteases during Trypanosoma cruzi metacyclogenesis. Expl Parasitol 73: $44-51$

Bontempi E., Franke de Cazzulo BM, Ruiz AM, Cazzulo JJ (1984) Purification and some properties of an acidic protease from epimastigotes of Trypanosoma cruzi. Comp Biochem Physiol 77B:599-604

Bouvier J, Bordier C, Vogel H, Reichelt R, Etges R (1989) Characterization of the promastigote surface protease of Leishmania as a membrane-bound zinc endopeptidase. Mol Biochem Parasitol 37:235-245

Bouvier J, Schneider P, Etges R, Bordier C (1990) Peptide substrate specificity of the membrane-bound metalloprotease of Leishmania. Biochemistry 29:10113-10119

Bower SM, Woo PTK (1977a) Morphology and host specificity of Cryptobia catostomi n. sp. (Protozoa: Kinetoplastida) from white sucker (Catostomus commersoni) in southern Ontario. Can J Zool 55:1082-1092

Bower SM, Woo PTK (1977b) Division and morphogenesis of Cryptobia catostomi (Protozoa: Kinetoplastida) in the blood of white sucker (Catostomus commersoni). Can J Zool 55:1093-1099

Bradford MM (1976) A rapid and sensitive method for the quantitation of microgram quantities of protein utilizing the principle of protein-dye binding. Analyt Biochem 72: $248-254$

Burreson EM (1982a) Trypanoplasmiasis in flounder along the Atlantic coast of the United States. In: Anderson DP, Dorson M, Dubourget Ph (eds) Les antigenes des microorganisms pathogens des poissons. Collection Fondation Marcel Merieux, Lyon, p 251-260

Burreson EM (1982b) The life cycle of Trypanoplasma bullocki (Zoomastigophorea: Kinetoplastida). J Protozool 29: $72-77$

Etges R (1992) Identification of a surface metalloproteinase on 13 species of Leishmania isolated from humans, Crithidia fasciculata, and Herpetomonas samuelpessoai. Acta Tropica 50:205-217

Garber GE, Lemchuk-Favel LT (1989) Characterization and purification of extracellular protease of Trichomonas vaginalis. Can J Microbiol 35:903-909

Greig S, Ashall F (1990) Electrophoretic detection of Trypanosoma cruzi peptidases. Mol Biochem Parasitol 39:31-38

Hames BD (1981) An introduction to polyacrylamide gel electrophoresis. In: Hames BD, Rickwood D (eds) Gel electrophoresis of proteins: a practical approach. IRL Press Limited, London, p 1-91

Harth G, Andrews N, Mills AA, Engel JC, Smith R, McKerrow JH (1993) Peptide-fluoromethyl ketones arrest intracellular replication and intercellular transmission of $T_{r y-}$ panosoma cruzi. Mol Biochem Parasitol 58:17-24

Knox DP, Redmond DL, Jones DG (1993) Characterization of proteinases in extracts of adult Haemonchus contortus, the ovine abomasal nematode. Parasitology 106:395-404

Lacks SA, Springhorn SS (1980) Renaturation of enzymes after polyacrylamide gel electrophoresis in the presence of sodium dodecyl sulfate. J Biol Chem 255:7467-7473

Li S, Woo PTK (1991) Anorexia reduces the severity of cryptobiosis in Oncorhynchus mykiss. J Parasitol 77:467-471

Li S, Woo PTK (1995) Efficacy of a live Cryptobia salmositica vaccine, and the mechanism of protection in vaccinated rainbow trout Oncorhynchus mykiss. J Vet Immunol Immunopathol 48:343-353

Li S, Woo PTK (1996) Effects of temperature and white sucker
(Catostomus commersoni) serum supplement on the in vitro multiplication of Cryptobia catostomi in cell-free culture medium. Parasitol Res 82:276-278

McKerrow JH (1989) Minireview: parasite proteases. Expl Parasitol 68:111-115

Munoz ML, Calderon J, Rojkind M (1982) The collagenase of Entamoeba histolytica. J Expl Med 155:42-51

Munoz ML, Lamoyi E, Leon G, Tovar R, Perez-Garcia J (1990) Antigens in electron-dense granules from Entamoeba histolytica as possible markers for pathogenicity. J Clin Microbiol 28:2418-2424

Nazareth M, Meirelles L, Juliano L, Carmona E, Silva SG, Costa EM, Murta ACM, Scharfstein J (1992) Inhibitors of the major cysteinyl proteinase (GP 57/51) impair host cell invasion and arrest the intracellular development of Trypanosoma cruzi in vitro. Mol Biochem Parasitol 52: $175-184$

North MJ (1992) The characteristics of cysteine proteases of parasitic protozoa. Biol Chem 373:401-406

North MJ, Coombs GH, Barry JD (1983) A comparative study of the proteolytic enzymes of Trypanosoma brucei, $T$. equiperdum, $T$. evansi, $T$. vivax, Leishmania tarentolae and Crithidia fasciculata. Mol Biochem Parasitol 9:161-180

North MJ, Walker M (1984) An analysis of intracellular proteolytic activities of Tetrahymena pyriformis GL. J Gen Microbiol 130:1977-1985

North MJ, Whyte A (1984) Purification and characterization of two acid proteinases from Dictyostelium discoideum. J Gen Microbiol 130:123-134

Piras MM, Henriquez D, Piras R, Nigri S (1985) The effect of proteolytic enzymes and protease inhibitors on the interaction T. cruzi-fibroblasts. Mol Biochem Parasitol 14: $151-163$

Sarath G, Motte RS de la, Wagner FW (1989) Protease assay methods. In: Beynon RJ, Bond JS (eds) Proteolytic enzymes: a practical approach. IRL Press, Oxford, p 25-56

Sitja-Bobadilla A, Woo PTK (1994) An enzyme-linked immunosorbent assay (ELISA) for the detection of antibodies against the pathogenic haemoflagellate, Cryptobia salmositica Katz, and protection against cryptobiosis in juvenile rainbow trout, Oncorhynchus mykiss (Walbaum), inoculated with a live vaccine. J Fish Dis 17:399-408

Thomas PT, Woo PTK (1988) Cryptobia salmositica: an in vitro study on the mechanism of anaemia in infected rainbow trout, Salmo gairdneri Richardson. J Fish Dis 11:425-431

Thomas PT, Woo PTK (1989) An in vitro study on the haemolytic components from Cryptobia salmositica (Sarcomastigophora: Kinetoplastida). J Fish Dis 12:389-393

Thomas PT, Woo PTK (1992) In vitro culture and multiplication of Cryptobia catostomi and experimental infection in white sucker (Catostomus commersoni). Can J Zool 70: 201-204

Wardlaw AC (1985) Practical statistics for experimental biologists. A Wiley-Interscience Publ, John Wiley \& Sons, Chichester

Woo PTK (1979) Trypanoplasma salmositica: experimental infections in rainbow trout, Salmo gairdneri. Expl Parasitol $47: 36-48$

Woo PTK (1987) Cryptobia and cryptobiosis in fishes. In: Baker JR, Muller R (eds) Advances in parasitology, Vol 26. Academic Press, London, p 199-237

Woo PTK (1991) Mammalian trypanosomiasis and piscine cryptobiosis in Canada and the United States. Bull Soc Vec Ecol 16:25-42

Woo PTK (1994) Flagellate parasites of fish. In: Kreier JP (ed) Parasitic protozoa, Vol 8. Academic Press, New York, p $1-80$ 
Woo PTK, Li S (1990) In vitro attenuation of Cryptobia salmositica and its use as a live vaccine against cryptobiosis in Oncorhynchus mykiss. J Parasitol 76:752-755

Woo PTK, Thomas PT (1991) Polypeptide and antigen profiles of Cryptobia salmositica, C. bullocki and C. catostomi (Sarcomastigophora: Kinetoplastida) isolated from fishes. Dis Aquat Org 11:201-205

Woo PTK, Thomas PT (1992) Comparative in vitro studies on

Responsible Subject Editor: W. Körting, Hannover, Germany virulent and avirulent strains of Cryptobia salmositica (Sarcomastigophora: Kinetoplastida). J Fish Dis 15:261-266 Zuo X, Woo PTK (1997) Natural antiproteases in rainbow trout, Oncorhynchus mykiss and brook charr, Salvelinus fontinalis and the in vitro neutralization of fish $\alpha 2$ macroglobulin by the metalloprotease from the pathogenic haemoflagellate, Cryptobia salmositica. Parasitology (in press)

Manuscript first received: October 15, 1996

Revised version accepted: February 6, 1997 